Vol. VIII No. 3, Desember 2015

P-ISSN : 1979-858X

Halaman 162-170

\title{
PENGARUH AUDIT TENURE, OPINI AUDIT TAHUN SEBELUMNYA, DAN DISCLOSURE TERHADAP OPINI AUDIT GOING CONCERN
}

\author{
M. Nur Fahmi \\ PT Permodalan BMT Ventura
}

\begin{abstract}
The purpose of this research is proving the effect of audit tenure, prior year audit opinion, and disclosure to going concern audit opinion. This research uses samples of mining and agriculture companies that listed at Indonesian Stock Exchange in 2011-2014. Based on purposive sampling method, total of samples of this research are 56 companies. The hypothesis in this research uses logistic regression. This research shows that prior year audit opinion has significant effect on the going concern audit opinion. Audit tenure and disclosure do not have significant effect on the going concern audit opinion.
\end{abstract}

Keywords: Audit Tenure, Prior Year Audit Opinion, Disclosure, And Going Concern Audit Opinion.

ABSTRAK: Penelitian ini bertujuan membuktikan pengaruh audit tenure, opini audit tahun sebelumnya, dan disclosure terhadap opini audit going concern. Penelitian ini menggunakan sampel perusahaan tambang dan agriculture yang terdaftar di Bursa Efek Indonesia (BEI) selama tahun 2011-2014. Berdasarkan metode purposive sampling, total sampel penelitian adalah sebanyak 56 perusahaan. Pengujian hipotesis dalam penelitian ini menggunakan regresi logistik. Penelitian ini menunjukkan bahwa opini audit tahun sebelumnya berpengaruh signifikan terhadap opini audit going concern. Audit tenure dan disclosure tidak berpengaruh signifikan terhadap opini audit going concern.

Kata Kunci: Audit Tenure, Opini Audit Tahun Sebelumnya, Disclosure, Dan Opini Audit Going Concern.

\footnotetext{
${ }^{1}$ Draft pertama: 20 September 2015; Revisi: 15 Oktober 2015; Diterima: 12 November 2015

Penulis dapat dikontak melalui: nurfahmi0712@gmail.com
} 


\section{PENDAHULUAN}

Laporan keuangan yang telah diaudit diibaratkan sebagai jembatan yang menghubungkan antara perusahaan dengan pemegang kepentingan. Laporan keuangan merupakan bagian yang tidak dapat terpisahkan dari suatu perusahaan, karena laporan keuangan merupakan salah satu media utama yang dapat digunakan oleh perusahaan untuk mengkomunikasikan informasi keuangannya kepada pihak yang berkepentingan (Rossa dan Rahardjo, 2013). Investor merupakan salah satu pihak pemegang kepentingan atas suatu perusahaan, karena salah satu sumber modal adalah dana dari investor. Sumber modal inilah yang bisa menjadi salah satu faktor atas keberlangsungan hidup suatu perusahaan. Salah satu referensi yang digunakan investor untuk mengambil keputusan berkaitan dengan investasinya adalah opini audit atas laporan keuangan perusahaan yang diberikan oleh auditor independen (Rossa dan Rahardjo, 2013). Oleh sebab itu, auditor harus mengupayakan menciptakan kondisi audit yang paling efektif. Salah satu kondisi yang diperlukan untuk menciptakan kondisi audit yang efektif adalah independensi auditor (Foroghi, 2012).

Namun, di balik itu semua ada beberapa kasus skandal audit yang mana hasil laporan audit tidak mencerminkan keadaan suatu perusahaan yang sebenarnya dan tentu saja melibatkan auditor di dalamnya, sehingga auditor menjadi pihak yang harus bertanggung jawab atas kasus tersebut, seperti kasus Enron, Worldcom, Xerox, dan lain-lain (Dewayanto, 2011). Tucker et al., (2003) dalam Ardiani et al. (2012) menemukan bahwa dari 228 perusahaan publik yang mengalami kebangkrutan, Enron dan 95 perusahaan lainnya menerima opini wajar tanpa pengecualian pada tahun sebelum terjadinya kebangkrutan.

Banyak hal yang melatarbelakangi atas bangkrutnya perusahaan-perusahaan besar tersebut. Faktor-faktor yang melatarbelakanginya dapat berasal dari faktor keuangan, faktor non keuangan, faktor pasar, bahkan dapat juga dari faktor pribadi dari orang-orang yang mengelola perusahaan itu sendiri. Maka dibutuhkannya suatu opini auditor atas keberlangsungan suatu perusahaan. Opini tersebut sangat dibutuhkan oleh para pemegang kepentingan terkait sikapnya terhadap suatu perusahaan. Opini audit going concern membantu investor untuk memutuskan akan berinvestasi atau tidak ke dalam perusahaan auditee yang terkena opini audit going concern (Ulya, 2012).

Indonesia yang memiliki letak geografis di daerah tropis dan dilewati garis katulistiwa mempunyai keuntungan tersendiri. Indonesia merupakan negara yang kaya akan sumber daya alamnya. Dengan melimpahnya sumber daya alam Indonesia maka terbukalah kesempatan untuk mengelola sumber daya tersebut. Oleh sebab itu banyak perusahaan yang berkecimpung di bidang itu. Bukan hanya perusahaan dalam negeri, perusahaan luar negeri seperti Chevron, Freeport, Petro China, dan lain-lain turut ambil bagian dalam mengelola sumber daya Indonesia.

Penelitian-penelitian terkait faktor-faktor yang mempengaruhi opini going concern diantaranya yaitu Dewayanto (2011), Ardiani et al. (2012), Foroghi (2012), Zulfikar dan Syafruddin (2013), Rossa dan Rahradjo (2013), Verdiana dan Utama (2013), dan Bedard et al. (2015). Penelitian ini meneliti terkait pengaruh audit tenure, opini audit tahun sebelumnya dan disclosure akan mempengaruhi opini audit going concern. Ross dan Rahardjo (2013) dan Junaidi dan Hartono (2010) menyatakan bahwa audit tenure berpengaruh terhadap penerimaan opini audit going concern. Namun berbeda dengan hasil penelitian yang dilakukan oleh Ulya (2012) yang menyatakan bahwa variabel audit tenure tidak berpengaruh signifikan terhadap penerimaan opini audit going concern. Zulfikar dan Syafruddin (2013) dan Ulya (2012) menyatakan bahwa opini audit tahun sebelumnya berpengaruh terhadap penerimaan opini audit going concern. Junaidi dan Hartono (2010) menyatakan bahwa disclosure berpengaruh secara signifikan terhadap dikeluarkannya opini going concern oleh auditor. Namun berbeda dengan hasil penelitian Astuti dan Darsono (2012) yang menyatakan bahwa disclosure tidak berpengaruh terhadap penerimaan opini going concern. 


\section{KERANGKA TEORI DAN PENGEMBANGAN HIPOTESIS}

\section{Tinjauan Literatur}

Jensen dan Meckling (1976) dalam Zulfikar dan Syafruddin (2013) mendefinisikan hubungan keagenan sebagai suatu kontrak yang mana satu atau lebih prinsipal (pemilik) menggunakan orang lain atau agen (manajer) untuk menjalankan aktivitas perusahaan. Agar terdapat timbal balik antara prinsipal dan agen, maka agen mendapatkan imbalan dari prinsipal berupa gaji, upah, bonus, dan lain-lain. Agen sebagai orang-orang yang mengelola perusahaan memiliki kepentingan tersendiri yaitu memaksimalkan imbalan dari prinsipal baik berupa gaji, bonus, insentif, dan lain-lain.

Adanya dua kepentingan antara prinsipal dan agen inilah yang kadang menyebabkan masalah bagi perusahaan, masalah ini biasa disebut dengan masalah keagenan. Masalah keagenan timbul karena adanya konflik kepentingan antara prinsipal dan agen (Zulfikar dan Syafruddin, 2013). Dalam kaitannya dengan penerimaan opini audit going concern, agen (manajemen) bertanggung jawab secara moral terhadap kelangsungan perusahaan yang dipimpinnya. Pemilik memberi wewenang kepada agen untuk melakukan operasional perusahaan, sehingga informasi lebih banyak diketahui oleh agen dibandingkan pemilik. Baik prinsipal maupun agen diasumsikan sebagai orang ekonomi rasional dan semata-mata termotivasi oleh kepentingan pribadi. Hal ini dapat memicu terjadinya konflik keagenan (Zulfikar dan Syafruddin, 2013).

Riahi dan Belkoui (2006:271) menyatakan going concern adalah Dalil kelangsungan usaha (going-concern postulate), atau dalil kontinuitas, menganggap bahwa entitas bisnis akan melanjutkan operasinya cukup lama untuk merealisasikan proyek, komitmen, dan aktivitasnya yang berkelanjutan.

Audit tenure merupakan lama waktu hubungan antara auditor dengan auditee. Lama waktu ini dihitung dengan bilangan tahun. Opini audit tahun sebelumnya merupakan opini audit yang diterima perusahaan pada satu tahun sebelumnya. Menurut Zulfikar dan Syafruddin (2013), opini audit going concern yang telah diterima auditee pada tahun sebelumnya akan menjadi faktor pertimbangan yang penting bagi auditor dalam mengeluarkan opini audit going concern pada tahun berjalan jika kondisi keuangan auditee tidak menunjukan tanda - tanda perbaikan atau tidak adanya rencana manajemen yang dapat direalisasikan untuk memperbaiki kondisi perusahaan.

Disclosure dapat didefinisikan sebagai pemberian informasi oleh perusahaan yang mungkin mempengaruhi keputusan investasi (Verdiana dan Utama, 2013). Pengungkapan informasi oleh perusahaan diperlukan oleh investor dalam mengambil keputusan. Untuk meyakinkan bahwa investor memperoleh kembalian yang dikehendaki dengan risiko tertentu, investor memerlukan informasi sebagai landasan keputusannya (Nuswandari, 2009).

\section{Pengembangan Hipotesis}

\section{Pengaruh audit tenure terhadap opini audit going concern}

Pesan pergantian Kantor Akuntan Publik (KAP) ini berawal dari kegagalan KAP Arthur Anderson di Amerika Serikat tahun 2001, yang gagal mempertahankan independensinya terhadap kliennya Enron, skandal ini melahirkan The Sarbanes-Oxley Act (SOX) tahun 2002 (Suparlan dan Andayani, 2010). Perikatan audit yang lama akan menjadikan auditor kehilangan independensinya, sehingga kemungkinan untuk memberikan opini audit going concern akan sulit (Ulya, 2012). Menurut Januarti (2009) dalam Rossa dan Rahardjo (2013) semakin lama hubungan klien dengan auditor dikhawatirkan akan mempengaruhi tingkat indepedensi auditor dalam memberikan pendapatnya, sehingga kemungkinan untuk memberikan opini audit going concern juga semakin kecil. 


\section{$\mathrm{H}_{1}$ : Audit tenure berpengaruh negatif terhadap penerimaan opini audit going concern.}

2. Pengaruh opini audit tahun sebelumnya terhadap opini audit going concern

Perusahaan yang mendapatkan opini audit going concern akan berdampak pada kemunduran harga saham, kesulitan dalam meningkatkan modal pinjaman, ketidak percayaan investor, kreditor, pelanggan dan karyawan. oleh karena itu perusahaan yang pada tahun sebelumnya telah menerima opini audit going concern, berpotensi secara signifikan menerima kembali opini going concern pada tahun sekarang (Zulfikar dan Syafruddin, 2013). Auditee yang menerima opini audit going concern pada tahun sebelumnya akan dianggap memiliki masalah kelangsungan hidupnya, sehingga semakin besar kemungkinan bagi auditor untuk mengeluarkan opini audit going concern pada tahun berjalan (Dewayanto, 2010).

\section{$\mathrm{H}_{2}$ : Opini audit tahun sebelumnya berpengaruh positif terhadap penerimaan opini audit going concern.}

\section{Pengaruh disclosure terhadap opini audit going concern}

Zulfikar dan Syafruddin (2013) menyatakan bahwa semakin luasnya informasi yang diungkapkan oleh perusahaan yang mengalami kondisi keuangan yang buruk, maka auditor akan lebih mudah dalam menemukan bukti dalam menilai kelangsungan usaha perusahaan. Sebagaimana yang diungkapkan oleh Ardiani et al. (2012) yang menyatakan bahwa adanya disclosure dari perusahaan tentang keraguan atas going concern terlebih bila disertai adanya rencana manajemen perusahaan untuk mengatasinya menunjukkan adanya ketidakmampuan perusahaan untuk mempertahankan kelangsungan hidupnya. Hal ini mengindikasikan adanya korelasi antara disclosure dengan opini audit going concern.

$\mathrm{H}_{3}$ : disclosure berpengaruh positif terhadap penerimaan opini audit going concern

\section{METODE PENELITIAN}

\section{Populasi dan Sampel Penelitian}

Populasi penelitian ini adalah perusahaan tambang dan agriculture yang terdaftar di BEI antara tahun 2011 hingga 2014. Sampel penelitian ini diambil dengan metode purposive sampling dan dikhususkan menggunakan dengan metode judgement sampling karena sampel dipilih berdasarkan kriteria khusus yang disesuaikan dengan tujuan. Kriteria pemilihan sampel penelitian ini adalah sebagai berikut:

1. Perusahaan tambang dan agriculture yang terdaftar di BEI antara tahun 2011 hingga 2014 yang tidak mengalami delisting.

2. Menerbitkan laporan auditor independen bersamaan dengan laporan keuangan yang telah diaudit antara tahun 2011 hingga 2014.

3. Mengalami laba bersih setelah pajak bernilai negatif paling tidak 2 periode laporan keuangan saat pengamatan.

\section{Metode Analisis Data}

Alat pengelolaan data untuk menganalisis penelitian ini adalah analisis regresi logistik (logistic regression) dengan bantuan Statistical Package for Social Science (SPSS) Ver. 22. Model yang digunakan dalam penelitian ini adalah sebagai berikut:

$$
G C=\beta \mathrm{o}+\beta_{1}(\text { Tenure })+\beta_{2}(\text { OTS })+\beta_{3}(\text { Disc })+\varepsilon
$$

dimana:

GC : Opini Audit Going Concern (1 untuk perusahaan yang 
menerima opini going concern, dan o untuk perusahaan yang tidak menerima opini going concern)

Bo : Konstanta

Tenure : Lama hubungan auditor dengan klien

OTS : Opini audit yang diterima tahun sebelumnya (Kategori 1 bila opini going concern (GCAO), o bila bukan (NGCAO)

Disc : Tingkat disclosure

$\boldsymbol{\beta 1}_{\mathbf{1}} \boldsymbol{\beta} \mathbf{3}$ : Koefisien regresi

$\varepsilon \quad:$ Koefisien error

\section{Operasional Variabel Penelitian}

1. Opini Audit Going Concern

Opini audit going concern merupakan variabel dependen yang mana variabel ini akan dipengaruhi oleh variabel independen lainnya. Opini audit going concern merupakan opini audit yang dikeluarkan oleh auditor untuk mengevaluasi apakah terdapat keraguan besar tentang kemampuan entitas untuk mempertahankan kelangsungan hidupnya untuk jangka waktu yang layak dan, jika berlaku, untuk mempertimbangkan kecukupan pengungkapan dalam laporan keuangan serta untuk mencantumkan paragraf penjelasan dalam laporannya yang mencerminkan kesimpulannya (SPAP, 2011). Variabel opini audit going concern diukur dengan menggunakan variabel dummy. Perusahaan yang mendapat opini audit going concern diberi kode 1, sedangkan perusahaan yang mendapat opini non going concern diberi kode o (Rossa dan Rahardjo, 2013).

2. Audit Tenure

Audit tenure merupakan lama waktu hubungan auditor dengan klien. Variabel audit tenure diukur dengan menggunakan skala interval sesuai dengan lama hubungan KAP dengan auditee. Tahun perikatan dimulai dengan angka 1 dan ditambah dengan satu untuk tahun-tahun berikutnya (Rossa dan Rahardjo, 2013)

3. Opini Audit Tahun sebelumnya

Auditee yang menerima opini audit going concern pada tahun sebelumnya akan dianggap memiliki masalah kelangsungan hidupnya, sehingga semakin besar kemungkinan bagi auditor untuk mengeluarkan opini audit going concern pada tahun berjalan (Dewayanto,2011). Variabel opini audit tahun sebelumnya diukur dengan menggunakan variable dummy. Opini audit going concern akan diberikan kode 1 sedangkan untuk opini audit non going concern akan diberikan kode o (Rossa dan Rahardjo, 2013).

4. Disclosure

Penentuan indeks dilakukan dengan menggunakan skor disclosure yang diungkapkan oleh perusahaan. Jika perusahaan mengungkapkan item informasi dalam laporan tahunannya, maka skor 1 akan diberikan dan jika item tersebut tidak diungkapkan, maka o akan diberikan. Kemudian dimasukkan dalam rumus sebagai berikut:

$$
\text { Disclosure Level }=\frac{\text { Jumlah skor disclosure yang dipenuhi }}{\text { Jumlah skor maksimum }}
$$




\section{HASIL DAN PEMBAHASAN}

\section{Deskripsi Objek Penelitian}

Populasi dalam penelitian ini adalah perusahaan tambang dan agriculture yang terdaftar di BEI antara tahun 2011 hingga 2014 dan tidak megalami delisting selama periode penelitian. Perusahaan tambang sangat rentan terhadap permasalahan kelangsungan hidup (going concern), misalnya kebijakan dari pemerintah terkait perizinan maupun harga komoditas tambang dunia yang sedang turun khususnya batubara dan emas. Kemudian perusahaan agriculture dipilih karena saat ini Indonesia tengah mendapatkan investasi yang terus mengalami peningkatan. Badan Koordinasi Penanaman Modal (BKPM) mencatat minat investasi di sektor pertanian terus mengalami peningkatan. Kenaikannya sampai 134,8\%, berdasarkan pengajuan izin prinsip yang diterima (Junida, 2015). Fokus penelitian ini adalah untuk menganalisis pengaruh audit tenure, opini audit tahun sebelumnya, dan disclosure terhadap opini audit going concern.

Tabel 4.1. Tahapan Seleksi Sampel dengan Kriteria

\begin{tabular}{|l|c|}
\hline \multicolumn{1}{|c|}{ Kriteria } & Jumlah \\
\hline $\begin{array}{l}\text { Jumlah perusahaan tambang dan agriculture yang terdaftar di } \\
\text { BEI tahun 2011 - 2014 dan tidak megalami delisting }\end{array}$ & $\mathbf{5 2}$ \\
\hline $\begin{array}{l}\text { Perusahaan tidak menerbitkan laporan auditor beserta laporan } \\
\text { keuangan secara lengkap }\end{array}$ & $(\mathbf{7})$ \\
\hline $\begin{array}{l}\text { Perusahaan yang tidak mengalami laba bersih negatif sekurang- } \\
\text { kurangnya dua tahun }\end{array}$ & $\mathbf{( 3 1 )}$ \\
\hline Jumlah perusahaan sampel & $\mathbf{1 4}$ \\
\hline Tahun pengamatan & $\mathbf{4}$ \\
\hline Jumlah sampel total selama periode penelitian & $\mathbf{6 6}$ \\
\hline
\end{tabular}

Sumber: data sekunder yang diolah (2015)

Hasil Uji Statistik Deskriptif

Berikut disajikan hasil uji statitik deskriptif yang akan dijelaskan dalam table $\mathbf{4 . 2}$ dibawah ini:

Tabel 4.2. Descriptive Statistics

\begin{tabular}{|l|r|r|r|r|r|}
\hline & $\mathrm{N}$ & Minimum & Maximum & Mean & Std. Deviation \\
\hline Opini Audit & 56 & .0 & 1.0 & .393 & .4928 \\
Tenure & 56 & 1.0 & 4.0 & 1.750 & .8790 \\
OTS & 56 & 0 & 1 & .36 & .483 \\
Disc & 56 & .4545 & .9697 & .798701 & .1304252 \\
Valid N (listwise) & 56 & & & & \\
\hline
\end{tabular}

\section{Pembahasan Hasil Penelitian}

Berdasarkan hasil pengolahan SPSS 22, menunjukkan nilai -2 Log Likehood awal dan akhir mengalami penurunan. Penurunan nilai -2 Log Likehood ini dapat diartikan bahwa dengan penambahan variabel bebas ke dalam model dapat memperbaiki model fit. Penurunan tersebut juga mnunjukkan model regresi yang baik atau model fit dengan data. Besarnya nilai koefisien determinasi ditunjukkan oleh nilai Nagelkerke $R$ Square. Nilai Nagelkerke R. Square sebesar 70,6\%, yang berarti variabel dependen dapat dijelaskan oleh variabel independen sebesar $70,6 \%$ dan selebihnya dijelaskan oleh variabel lain di luar model peneltian. 
Hasil pengujian Hosmer and Lemeshow's Test menunjukkan nilai signifikansi sebesar 0,407 , nilai tersebut lebih besar nilainya di atas o,o5 yang berarti hipotesis o $\left(\mathrm{H}_{\mathrm{o}}\right)$ diterima. Berdasarkan data tersebut, model mampu memprediksi nilai observasinya sehingga model ini dapat digunakan untuk analisis selanjutnya. Pada Correlation Matrix menunjukkan tidak ada nilai koefisien korelasi yang nilainya lebih besar dari o,9, maka tidak ada gejala multikolinearitas yang serius antara variabel bebasnya. Selanjutnya disajikan tabel matriks korelasi.

\section{Pengujian Hipotesis}

Tabel 4.3. Hasil Uji Koefisien Regresi Logistik

\begin{tabular}{|l|r|r|r|r|r|r|l|}
\hline & \multicolumn{1}{|c|}{ B } & \multicolumn{1}{c|}{ S.E. } & \multicolumn{1}{c|}{ Wald } & \multicolumn{1}{c|}{ df } & \multicolumn{1}{c|}{ Sig. } & \multicolumn{1}{|c|}{$\operatorname{Exp(B)}$} & Keterangan \\
\hline Tenure & -.198 & .550 & .130 & 1 & .718 & .820 & Tidak Signifikan \\
OTS & 4.631 & 1.162 & 15.877 & 1 & .000 & 102.622 & Signifikan \\
Disc & 10.011 & 6.185 & 2.620 & 1 & .106 & $\mathbf{2 2 2 6 5 . 6 1 8}$ & Tidak Signifikan \\
Constant & -10.052 & 5.126 & 3.846 & 1 & .050 & .000 & \\
\hline
\end{tabular}

Sumber: data sekunder yang diolah (2015)

Hasil pengujian atas koefisien regresi menghasilkan model sebagai berikut: Going Concern $=-10,052-0,198$ Tenure + 4,631 OTS + 10,011 Disc

1. Pengaruh Audit Tenure (Tenure) terhadap Opini Audit Going Concern

Variabel Tenure menunjukkan koefisien regresi negatif sebesar -0,198 dengan tingkat signifikansi sebesar 0,820 . Nilai signifikasi lebih besar dari $\alpha=5 \%$. Nilai signifikansi lebih besar dari $\alpha=5 \%$, maka $\mathrm{H}_{1}$ tidak berhasil didukung (ditolak). Hasil penelitian ini tidak konsisten dengan penelitian yang dilakukan oleh Knechel dan Vanstralen (2007), Dao et al. (2008), Junaidi dan Hartono (2010), dan Rossa dan Rahardjo (2013) yang menyatakan bahwa audit tenure berpengaruh signifikan terhadap penerimaan opini audit going concern. Namun penelitian ini sejalan dengan hasil penelitian yang dilakukan oleh Dewayanto (2011), Ardiani et al. (2012), dan Ulya (2012).

Hasil penelitian ini menunjukkan bahwa sekalipun dengan masa perikatan tugas audit yang lama tidak mempengaruhi independensi auditor. Oleh sebab itu bisa jadi lama waktu KAP bertugas pada suatu auditee ditentukan oleh peraturan tersebut.

2. Pengaruh Opini Tahun sebelumnya (OTS) terhadap Opini Audit Going Concern

Variabel OTS menunjukkan koefisien regresi positif sebesar 4,631 dengan tingkat signifikansi sebesar o,ooo. Nilai signifikansi lebih besar dari $\alpha=5 \%$, dengan demikian maka hipotesis $\mathrm{H}_{2}$ berhasil didukung. Hasil ini konsisten dengan penelitian yang dilakukan oleh Kartika (2012), Zulfikar dan Syafruddin (2013), dan Syaifuddin dan Fitriyani (2014) yang menyatakan bahwa opini audit tahun sebelumnya berpengaruh signifikan terhadap opini audit going concern. Auditee yang menerima opini audit going concern pada tahun sebelumnya akan dianggap memiliki masalah kelangsungan hidupnya, sehingga semakin besar kemungkinan bagi auditor untuk mengeluarkan opini audit going concern pada tahun berjalan (Dewayanto, 2011).

3. Pengaruh Disclosure terhadap Opini Audit Going Concern

Variabel Disc menunjukkan koefisien regresi positif sebesar 10,011 dan tingkat signifikansinya sebesar 0,106 . Nilai signifikansi variabel ini lebih besar dari pada $\alpha=$ 
$5 \%$, dengan kata lain $\mathrm{H}_{3}$ tidak berhasil didukung (ditolak). Penelitian ini tidak konsisten dengan penelitian yang telah dilakukan oleh Haron et.al (2009), Rossa dan Rahardjo (2013), dan Verdiana dan Utama (2013) yang menyatakan bahwa disclosure berpengaruh signifikan terhadap penerimaan opini audit going concern. Namun penelitian ini sejalan dengan hasil penelitian yang dilakukan oleh Astuti dan Darsono (2012), dan Santosa dan Wiyono (2012) yang menyatakan bahwa disclosure tidak berpengaruh terhadap penerimaan opini audit audit going concern oleh auditor. Hal ini disebabkan karena item pengungkapan yang harus disampaikan oleh perusahaan telah diatur dalam keputusan Ketua Badan Pengawas Pasar Modal dan Lembaga Keuangan Nomor KEP-134/BL/2006 Peraturan Nomor X.K.6

\section{SIMPULAN}

Berdasarkan hasil uji regresi logistik menunjukkan bahwa audit tenure secara statistik tidak berpengaruh terhadap opini audit going concern selama 4 tahun pengamatan (20112014). Opini audit tahun sebelumnya secara statistik berpengaruh terhadap opini audit going concern selama 4 tahun pengamatan (2011-2014). Disclosure secara statistik tidak berpengaruh terhadap opini audit going concern selama 4 tahun pengamatan (2011-2014).

Penelitian selanjutnya diharapkan menggunakan seluruh sektor perusahaan sebagai sampel. Selain itu periode pengamatan penelitian sebaiknya ditambah. Kemudian diharapkan menambah variabel lain agar dapat terlihat faktor lain yang mempengaruhi opini audit going concern baik keuangan maupun non keuangan seperti opinion shopping, ukuran perusahaan, kondisi keuangan, reputasi auditor dan debt default.

\section{PUSTAKA ACUAN}

Ardiani, Nurul, Emrinaldi Nur DP dan Nur Azlina. “ Pengaruh Audit Tenure, Disclosure, Ukuran Kap, Debt Default, Opinion Shopping, dan Kondisi Keuangan terhadap Penerimaan Opini Audit Going Concern pada Perusahaan Real Estate dan Property di Bursa Efek Indonesia”, Jurnal Ekonomi, Volume 20, Nomor 4 Desember, 2012.

Arsianto, Maydica Rossa dan Shiddiq Nur Rahardjo. "Faktor-Faktor yang Mempengaruhi Penerimaan Opini Audit Going Concern", Diponegoro Journal Of Accounting, Volume 2, Nomor 3, Halaman 1, 2013.

Astuti, Irtani Retno dan Darsono. "Pengaruh Faktor Keuangan dan Non Keuangan terhadap Penerimaan Opini Audit Going Concern", Diponegoro Journal Of Accounting, Volume 1, Nomor 2, Tahun 2012, Halaman 1-10, 2012.

Bedard, Jean C, Johnstone, Karla M. "Audit Partner Tenure and Audit Planning and Pricing", American Accounting Association, 2015.

Dao, Mai, Suchismita Mishra, dan K. Raghunandan. "Auditor Tenure and Shareholder Ratification of the Auditor", Accounting Horizons, Vol. 22, No. 3, pp. 297-314, 2008.

Dewayanto, Totok. "Analisis Faktor-Faktor yang Mempengaruhi Penerimaan Opini Audit Going Concern pada Perusahaan Manufaktur yang terdaftar di Bursa Efek Indonesia”, Fokus Ekonomi, Vol. 6 No. 1, hal 81-104, Juni 2011.

Foroghi, Daroush. "Audit Firm Size and Going Concern Reporting Accuracy", Interdiciplinary Journal of Contemporary Research in Bussines, Vol 3, No. 9, January 2012.

Ghozali, Imam. "Aplikasi Analisis Multivariate dengan program IBM SPSS 21", Edisi 7 Cetakan VII, Badan Penerbit Universitas Diponegoro, Semarang, 2013.

Haroon, Hasnah, Bambang Hartadi, Mahfooz Ansari, dan Ishak Ismail. "Factors influencing auditor's going concern opinion”, Asian academy of Management Journal, Vol. 14 No.1 :1-19. 2009 
Institut Akuntan Publik Indonesia. "Standar Profesional Akuntan Publik", Salemba Empat, Jakarta, 2011.

Junaidi dan Jogiyanto Hartono. "Faktor Non Keuangan pada Opini Going Concern", Simposium Nasional Akuntansi XIII Purwokerto, 2010.

Junida, Ade Irma. "Investasi di Pertanian Kian Gembur" artikel diakses tanggal 23 Juli 2015 dari http://industri.kontan.co.id/news/investasi-di-pertanian-kian-gembur

Nuswandari, Cahyani. "Pengungkapan Pelaporan Keuangan dalam Perspektif Signalling Theory”. Kajian Akuntansi Hal: 48-57, Vol. 1 No.1, 2009.

Riahi, Ahmed dan Belkaoui. "Accounting Theory", Buku Satu, edisi 5, Salemba Empat, Jakarta, 2006.

Santoso, Eko Budi dan Ivan Yudhistira Wiyono. "Pengaruh Reputasi Auditor, Prediksi Kebangkrutan, Disclosure dan Leverage terhadap Penerimaan Opini Audit Going Concern", Forum Bisinis \& Keuangan I, hal 185-195, 2012.

Suparlan dan Andayani. "Analisi Empiris Pergantian Kantor Akuntan Publik Setelah Ada Kewajiban Rotasi Audit”, Simposium Nasional Akuntansi XIII Purwokerto, 2010.

Syaifuddin, Ahmad dan Fitriyani. "Opini Going Concern, Tingkat Ketergantungan Auditor pada Klien dan Pergantian Auditor", Simposium Nasional Akuntansi XVII Lombok, 2014.

Ulya, Alfaizatul. "Opini Audit Going Concern: Analisis berdasarkan Faktor Keuangan dan Faktor Non Keuangan”, Accounting Analys Journal 1 (1), 2012.

Verdiana, Komang Anggita dan I Made Karya Utama. "Pengaruh Reputasi Auditor, Disclosure, Audit Client Tenure pada Kemungkinan Pengungkapan Opini Audit Going Concern”, E-Jurnal Akuntansi Universitas Udayana 5·3:530-543, 2013 